\author{
Anna Maria Myszka-Gustafsson
}

Albins folkhögskola

\title{
Szwedzkie uniwersytety ludowe - idea, współczesność i przyszłość z perspektywy ich nauczyciela
}

\author{
Swedish folk high schools - the idea, the present and the \\ future from the perspective of their teacher
}

\begin{abstract}
Streszczenie. Artykuł prezentuje wybrane zagadnienia dotyczące założeń, obecnego funkcjonowania i przyszłości uniwersytetów ludowych (folkhögskolor) w Szwecji, przypominając jednocześnie wybrane powojenne publikacje na ten temat, które ukazały się w języku polskim lub zostały przygotowane przez polskich autorów dla czytelnika po stronie szwedzkiej. Całość została zaprezentowana z punktu widzenia nauczyciela jednej z placówek tego typu Albins folkhögskola w Landskronie (Skania). Autorka obszerniej ukazuje działaniami własnej placówki na rzecz edukacji mieszkańców regionu na tle głównych kierunków przemian, zachodzących w szwedzkich uniwersytetach ludowych.
\end{abstract}

Słowa kluczowe: nieformalna edukacja dorosłych, uniwersytet ludowy, edukacja dorosłych w Szwecji, Albins folkhögskola.

Summary. The paper shows selected issues on the assumptions of the current and future operation of the folk high schools in Sweden, also recalling selected post-war publications on this subject, which appeared in the Polish language or have been prepared by the Poles for the Swedish reader. The issue was presented from the point of view of a teacher of one of the institutions of this sort - Albins folkhögskola in Landskrona (Skåne). The author shows extensively educational activities of her own institution for adult population of the region. She does this on the background of the main directions of the changes taking place in the Swedish folk high schools.

Keywords: non-formal adult education, folk high school, adult education in Sweden, Albins Folk High School. 


\section{Wprowadzenie}

Szwedzkie uniwersytety ludowe są miejscem skupiającym ludzi o różnych doświadczeniach, ideach i poglądach, umożliwiającym spotkania i interakcje w środowisku edukacji nastawionym na rozwój oświaty dla dorosłych. Dorośli podejmujący naukę na uniwersytetach ludowych reprezentują nie tylko zróżnicowane środowiska kulturalno-społeczne, ale różnią się również tym, co ich skłoniło do wyboru właśnie uniwersytetu ludowego. Część słuchaczy szuka zrozumienia skomplikowanej rzeczywistości, w której się znajdują i działają, część pragnie znaleźć właściwe ukierunkowanie swojej przyszłości, część chce po prostu zdobyć bilet wstępu na dalsze studia w szkołach wyższych i uniwersytetach.

\section{Stan wiedzy o szwedzkich uniwersytetach ludowych wśród Polaków}

Wiedza o szwedzkich uniwersytetach ludowych (szw. folkhögskola) jest w Polsce stosunkowo duża. To zasługa prac takich polskich autorów jak: Lucjan Turos (Turos, 1967; 1974), Agnieszka Bron-Wojciechowska (Bron-Wojciechowska, 1977), Jadwiga Nowak (Nowak, 1985), Wit Wojtowicz (Wojtowicz, 1966; 1991), Sulisława Byczkowska (Byczkowska \& Maliszewski, 2005), Józef Półturzycki (Półturzycki, 2009; 2010) czy Tomasz Maliszewski (Maliszewski, 2003a; 2003b; 2003c; 2007; 2014a) oraz autorów szwedzkich publikujących w Polsce - Alfreda Pettersona (Petterson, 1947), Ingve Kasimira (Kasimir, 1987), Paula Reichberga (Reichberg, 2003), Bengta Halla (Hall, 1996), Hansa Hovenberga (Hovenberg \& Maliszewski, 1996; Hovenberg, 2003) i Kåre Olssona (Olsson, 2003). Jak widać z powyższego zestawienia, wyższe szkoły ludowe w wydaniu szwedzkim budziły przez lata bardzo duże zainteresowanie wśród andragogów i oświatowców z kraju sąsiada $z$ drugiej strony Morza Bałtyckiego.

Należy dodać, że opracowania dotyczące analizy działań folkhögskolor przygotowane przez Polaków pojawiają się także po stronie szwedzkiej (i nie tylko). Przykładem takiej publikacji może być książka Wita Wojtowicza wydana w połowie lat 80 . XX wieku, która miała być odpowiedzią na zapotrzebowanie imigrantów z PRL-u na wiedzę o tych placówkach (Wojtowicz, 1985), oraz opublikowana przed kilku laty w znanej skandynawskiej serii wydawniczej z zakresu edukacji dorosłych „Vuxentubildarcentrums skriftserie" książka Tomasza Maliszewskiego (Maliszewski, 2008a), która spotkała 
się z dużym zainteresowaniem szwedzkich kręgów andragogicznych ${ }^{1}$. Artykuł tego ostatniego na temat tradycji i współczesności szwedzkich wyższych szkół ludowych został również opublikowany w ubiegłym roku w amerykańskim „Universal Journal of Educational Research” (Maliszewski, 2014b).

Wydaje się, że duży wpływ na znajomość szwedzkich uniwersytetów ludowych w Polsce wywarła również wieloletnia, bo datowana od początku lat 60. XX wieku, instytucjonalna współpraca szwedzkich i polskich placówek edukacji dorosłych ${ }^{2}$. Przez wiele lat rozwijała się ona bowiem wzorcowo - wyróżniając się na tle projektów podejmowanych przez Szwedów z innymi krajami (S. W. 1966; Hovenberg, 1976; Maliszewski, 1997; Maliszewski, 2008b; Thell, 2014).

\section{Przemiany i kierunki pracy szwedzkich uniwersytetów ludowych w XXI wieku}

Przyglądając się bliżej uniwersytetom ludowym w Szwecji, można stwierdzić, że u zarania swojej działalności stwarzały one możliwość zdobycia edukacji tak zwanym rezerwom intelektualnym szwedzkiego społeczeństwa. Pod pojęciem rezerwy intelektualnej rozumie się uzdolnionych ludzi dorosłych pragnących się kształcić, którzy to z różnych przyczyn, ekonomicznych, kulturalnych czy środowiskowych, nie mieli możliwości zdobycia wykształcenia w szkołach podstawowych czy licealnych. Zadaniem uniwersytetów ludowych było wyrównanie różnic edukacji i podnoszenie poziomu wykształcenia społeczeństwa. W ostatnim dwudziestoleciu zauważa się jednak, że o przyjęcie na uniwersytety ludowe ubiegają się coraz częściej młodzi ludzie, którzy z różnych powodów nie znaleźli swojego miejsca w ramach obowiązkowego systemu edukacji czy też stracili bardzo wcześnie chęć i zainteresowanie zdobycia wykształcenia na poziomie dziewięcioletniej szkoły podstawowej czy trzyletniej szkoły średniej.

1 W krótkim czasie po opublikowaniu monografii T. Maliszewskiego ukazał się w szwedzkich czasopismach branżowych, dotyczących pedagogiki i oświaty dorosłych, szereg bardzo pochlebnych recenzji - m.in.: Stelana Boozona („Mimer” 10/2008), Brigitty Tingdal („Folkhögskolan” 8/2008), Ingemara Sallnäsa („Forskning om folkbildning” 2/2008), Andersa Ekmana ("Information från Föreningen för folkbildningsforskning" 10/2008).

2 Autorka niniejszego artykułu przypomina ten fakt $z$ dużą osobistą satysfakcją, gdyż ma ona swój własny wkład w rozwój wspólnych szwedzko-polskich projektów oświatowych, podobnie jak przywoływana w tym artykule Albins folkhögskola - placówka, w której obecnie pracuje (zob. np.: Thell, 2014). 
Dla wielu młodych ludzi nauka na uniwersytecie ludowym zastępuje brak pracy i częściej jest alternatywnym rozwiązaniem problemu bezrobocia niż prawdziwym pragnieniem zdobycia wiedzy i świadectwa ukończenia szkoły średniej. Sytuacja ta wpływa radykalnie na kształtowanie programów nauczania, wybór kursów i metodykę nauczania. Proces zdobywania wiedzy jest uzależniony od zainteresowania nauką lub jego brakiem u słuchaczy. Ogólnie rzecz biorąc, można jednak stwierdzić, że uniwersytety ludowe są formą kształcenia i wykształcenia, którą wybiera się dobrowolnie i z pełną świadomością tego, że różni się ona zasadniczo od innych form edukacji dorosłych w Szwecji.

W Szwecji istnieje i działa obecnie 150 uniwersytetów ludowych. Spośród nich 107 znajduje się pod patronatem szwedzkich ruchów społecznych, organizacji pozarządowych oraz różnych fundacji; 42 uniwersytety ludowe prowadzone są przez wojewódzkie władze terytorialne i regiony, a jeden przez lokalne władze miejskie (FIN 2012a; FIN 2012b). Myślą przewodnią, uzasadniającą konieczność istnienia uniwersytetów ludowych w Szwecji jako pozaszkolnych i autonomicznych placówek kształcenia dorosłych, jest fakt, że różnią się one zasadniczo od pozostałych placówek edukacyjnych, integrując jednocześnie swoją działalność merytoryczną i dydaktyczną w ramach całego systemu kształcenia. Przepisy prawne wprowadzone od roku oświatowego 2003/2004 (por. np.: Ismailov \& Maliszewski, 2003) pozwoliły Narodowej Radzie Edukacyjnej na definitywne zrównanie formy kształcenia w obowiązkowej szkole licealnej z edukacją na poziomie szkoły średniej prowadzonej przez uniwersytety ludowe. Przez to samo stały się one placówkami podlegającymi jednolitym przepisom oświatowym.

W przeważającej większości uniwersytetów ludowych w Szwecji prowadzona jest dzisiaj żywa dyskusja w gronach członków zarządów poszczególnych szkół, rektorów (dyrektorów) uniwersytetów ludowych, wykładowców oraz personelu administracyjnego na temat istoty ducha i ideologii kształcenia dorosłych. Idea kształcenia dorosłych utożsamiana jest niejednokrotnie $\mathrm{z}$ istotą ducha powszechnej oświaty, powstałej u zarania istnienia uniwersytetów ludowych. Niekiedy występują ostre starcia między zwolennikami tradycyjnej definicji oświaty i wykształcenia dorosłych a zwolennikami pragnącymi dostosować pojęcia oświaty i wykształcenia do realiów oraz dzisiejszych potrzeb obywateli. Dyskutuje się i analizuje to, co różni zdobywanie wiedzy i umiejętności oraz sposób budowania postaw prospołecznych (obywatelskich) w uniwersytetach ludowych od zdobywania wiedzy w innych placówkach edukacji dorosłych, takich jak na przykład „klasyczne” szkoły dla doro- 
słych prowadzone przez poszczególne komuny (KomVux) czy też różnego rodzaju prywatne szkoły $\mathrm{i}$ instytucje szkoleniowe.

Nasuwa się więc zasadnicze pytanie: czym różnią się współcześnie mimo że podlegają jednolitym przepisom oświaty, obowiązującym w całym systemie kształcenia -uniwersytety ludowe od innych placówek edukacyjnych?

Otóż charakterystyczne dla uniwersytetów ludowych jest to, że nauka odbywa się w mniejszych, spoistych i jednolitych grupach słuchaczy, gdzie interdyscyplinarne podejście do wiedzy dominuje nad zagłębianiem się $\mathrm{w}$ istotę poszczególnych przedmiotów szkolnych. Słuchacze uniwersytetów ludowych mają możliwość wykazania swojej dotychczasowej wiedzy i zdobywania nowej w formie tematycznie zespolonych prac specjalnych i w projektach, gdzie szczególny nacisk kładziony jest na krytyczne badanie źródeł oraz na interakcje członków grupy wykonującej dane zadanie. W ramach konsultacji między wykładowcami a słuchaczami planowane są i realizowane wyjazdy szkolne, spotkania z różnymi instytucjami i władzami, seminaria i prace grupowe skupiające się na wymianie doświadczeń i własnych konkluzji. Te inicjatywy zostaną poddane krytycznej i skrupulatnej analizie dotyczącej ich sedna oraz przyczyn powstania. Myślą przewodnią jest więc łączenie praktyki z teorią i holistyczne podejście do potrzeb, doświadczeń, umiejętności i wiedzy poszczególnych słuchaczy w kontekście realiów społeczno-kulturalnych, w których znajdują się i działają.

Warto też przyjrzeć się danym statystycznym, które mówią „same za siebie" i w pełni uzasadniają potrzebę egzystencji uniwersytetów ludowych i oświaty dla dorosłych w Szwecji. I tak na przykład w 2011 roku prowadzono naukę w uniwersytetach ludowych w 93\% na tak zwanych długich kursach, obejmujących od dwóch do sześciu semestrów szkolnych i upoważniających do dotacji państwowej, a pozostałe $7 \%$ była to nauka prowadzona na kursach krótkich trwających od jednego do kilku tygodni; 43\% stanowiła nauka na kursach ogólnokształcących, Allmän linje, zapewniających ogólne przygotowanie do dalszych studiów i zdobycie kompetencji w zakresie szkoły podstawowej lub średniej; 50\% stanowiły zaś kursy ukierunkowane o szczególnym profilu, na których słuchacze uniwersytetów ludowych pogłębiają swoją wiedzę w zakresie interesujących ich przedmiotów, niejednokrotnie na poziomie pomaturalnym. Do typowych kursów długich tego rodzaju należą wszelkie kursy rzemiosła artystycznego, teatralne, muzyczne, językowe, kursy ochrony środowiska i kursy poruszające aspekt globalizacji świata. Na większości z tych kursów nie można zdobyć kompetencji formalnych, ale zdarzają się i takie kursy specjalne, które łączą w sobie charakter ogólnokształcący nauki, upoważniający do dalszych studiów ze specyficz- 
nym uprofilowaniem treści danego kursu. Obecnie istnieje około 70 kursów specjalnych o szczególnym profilu i można je znaleźć niemalże na każdym uniwersytecie ludowym w Szwecji (FIN 2012a; FIN 2012b).

W 2011 roku na omówione wyżej kursy długie uczęszczało około 55200 słuchaczy - z czego 23540 osób na kursy ogólnokształcące (Allmän linje). Interesujące jest zapewne i to, że $60 \%$ wszystkich słuchaczy kursów ogólnokształcących oraz $64 \%$ słuchaczy kursów specjalistycznych to kobiety. Z kolei kursy krótkie były przedmiotem zainteresowania 20000 osób (FIN 2012a; FIN 2012b).

Na uwagę zasługuje to, że w ostatnich latach powstało w ramach kursów krótkich wiele tak zwanych kursów na zlecenie - zamawianych i często opłacanych przez różnego rodzaju instytucje lub władze państwowe i lokalne. Powstają one niejednokrotnie w celu walki z bezrobociem w danym środowisku lokalnym czy regionie kraju. Biorący udział w kursach tego rodzaju mają możliwość zapoznania się z mechanizmami i wymaganiami rynku pracy oraz udziału w zajęciach związanych z przełamywaniem różnego rodzaju oporów i przeszkód stojących na drodze do podjęcia zatrudnienia. We wspomnianym roku 2011 w takich kursach motywacyjnych wzięło udział około 2800 osób.

Należy również wspomnieć, że poza wskazanymi już różnego rodzaju kursami, które prowadzone są przez współczesne szwedzkie uniwersytety ludowe, organizują one znaczną ilość seminariów, wykładów i imprez kulturalno-oświatowych adresowanych przede wszystkim do mieszkańców miejscowości, w których są zlokalizowane. We wskazanym już roku 150 działających w Szwecji uniwersytetów ludowych było organizatorami i gospodarzami aż 2880 tego typu przedsięwzięć edukacyjnych. Wśród ich uczestników również przeważały kobiety (55 \%), które chętniej niż mężczyźni brały udział zwłaszcza w programach kulturalno-oświatowych, niezależnie od ich treści czy charakteru (FIN 2012a; FIN 2012b).

Szwedzkie uniwersytety ludowe mają, jak wiadomo również w Polsce (por. np.: Maliszewski 2007; Maliszewski 2008a), długoletnie tradycje oświatowo-wychowawcze, sięgające aż do drugiej połowy wieku XIX. Wiele uniwersytetów ludowych posiada internaty i prowadzi kształcenie obywatelskie opierające się na bogatych doświadczeniach szerzenia ogólnej oświaty i kultury w celu umożliwienia ludności kierowania własnym życiem. Dostarczają one również wiedzy przydatnej do walki o wpływ jednostki na życie społeczne i polityczne, umożliwiają uczestnictwo słuchaczy w przyszłej działalności związkowej, kulturalnej czy też opartej na zasadzie wolontariatu. 


\section{Z działań Albins folkhögskola}

W ostatnich dziesięcioleciach powstało jednak wiele nowych placówek, które nie posiadają internatowej tradycji i - co za tym idzie - preferują wyłącznie ogólnokształcące i specjalne kursy dzienne, które nie kładą nacisku na stronę wychowawczą internatu w edukacji dorosłych. Ażeby zilustrować ten nowy typ uniwersytetu ludowego, pozwolę sobie krótko zaprezentować uniwersytet ludowy, na którym już od dwunastu lat wykładam język szwedzki i literaturę, podstawy psychologii i religioznawstwo. Albins folkhögskola, którego jestem pracownikiem, należy do typowych uniwersytetów nowej generacji, to znaczy niewielkich placówek edukacyjnych powstałych w środowiskach miejskich i podmiejskich - ściśle związanych z potrzebami edukacji ich mieszkańców.

Uniwersytet ludowy Albins folkhögskola jest jednym z 17 uniwersytetów ludowych w regionie Skanii. Znajduje się on pod patronatem i zarządem Szwedzkiej Organizacji Związków Zawodowych - LO Skåne, 21 branżowych związków zawodowych z północnozachodniej części Skanii oraz Towarzystwa Oświaty Robotniczej - ABF Skåne (Albins folkhögskola 2014). Placówka usytuowana jest w miasteczku portowym Landskrona (35000 mieszkańców), w pobliżu większego, drugiego co do wielkości na terenie Szwecji portu Helsingborg. Albins folkhögskola prowadzi trzy typy długich kursów, na których studiuje nieco ponad 90 słuchaczy:

- dwuletni ogólnokształcący kurs (Allmän linje) o profilu społecznym, przygotowujący do podjęcia studiów wyższych;

- jednoroczny pomaturalny kurs specjalistyczny o uprofilowaniu na zagadnienia ochrony środowiska i problematykę globalizacji świata;

- dwuletni pomaturalny kurs zawodowy, kształcący przyszłych publicystów, literatów i poetów (Skrivarlinjen).

Ponadto oferuje wiele kursów krótkich, dostosowanych przede wszystkim do potrzeb szkolenia członków różnych organizacji związków zawodowych, jak na przykład zajęcia z prawa pracy czy ćwiczenia dotyczące taktyki negocjacji. Uniwersytetem ludowym kierują dwaj rektorzy/dyrektorzy przy współpracy z 10 wykładowcami i 3 osobami zajmującymi się administracją placówki.

Od kilku lat prowadzone są również dwunastotygodniowe kursy motywacyjne dla bezrobotnej młodzieży z Landskrony i Helsingborga. Kursy te oparte są na ścisłej współpracy między uniwersytetem ludowym a instytucjami pośrednictwa pracy w obu tych miastach. Co czwarty młody człowiek 
w Szwecji nie ukończył szkoły średniej, a nawet podstawowej, a co za tym idzie - brakuje mu kompetencji formalnej pozwalającej na podjęcie wielu oferowanych stanowisk pracy. Sytuacja ta obciąża budżet państwa kosztem około 6 miliardów koron rocznie. Także w społeczności lokalnej, w której działa nasza placówka, sytuacja wysokiego bezrobocia wśród młodych ludzi jest bardzo niebezpieczna społecznie. Wzrosło ono bowiem w Landskronie w ostatnim czasie aż do 27\%. Państwo przygotowało system dotacji celowych na zwalczanie bezrobocia wśród młodych Szwedów. Co roku ubiegają się o nie również uniwersytety ludowe. Właśnie z tego rodzaju funduszy dotowane są wspomniane wyżej kursy motywacyjne dla młodzieży poszukującej pracy prowadzone w Albins folkhögskola. Placówka nasza podejmuje ogromne starania, aby przeciwdziałać marginalizacji społecznej młodzieży i ma w tym zakresie duże doświadczenie.

Zarząd uniwersytetu ludowego Albins folkhögskola wytyczył cele i zadania placówki, które wykładowcy i personel konsekwentnie realizują. Są one oparte na określonych wartościach społecznych i etycznych, wyrażonych w statucie szkoły. Na miejscu honorowym znajdują się takie wartości jak: solidarność, człowieczeństwo, demokracja i sprawiedliwość, które zobowiązują do odpowiednich postaw wobec słuchaczy i zdobywania przez nich wiedzy. Każdemu studiującemu w Albins folkhögskola udostępnia się studia według jego własnych możliwości i zdolności, pomagając mu jednocześnie w udoskonalaniu własnej świadomości życiowej oraz zrozumieniu świata i środowiska, którego kształcący się słuchacz jest nieodzowną częścią. Wykładowcy i cały personel są głęboko przekonani, że praca dydaktyczna i wychowawcza naszego uniwersytetu ludowego jest ważnym ogniwem w rozwoju społeczności lokalnej miasta Landskrona i nieodzowną częścią procesu budowania dojrzałej demokracji. Oferując nasze kursy szerokim kręgom odbiorców, popularyzując wiedzę oraz realizując zadania szeroko rozumianej animacji społeczno-kulturalnej środowiska lokalnego przyczyniamy się z pewnością do bardziej zrównoważonego rozwoju miasta i poprawy sytuacji jego mieszkańców (zob. też: Tingdal, 2012, s. 20-24).

\section{Zakończenie}

Idea uniwersytetów ludowych narodziła się w okresie historycznym, kiedy Szwecja stała przed zadaniem podjęcia daleko idących zmian strukturalnych życia społecznego, kulturalnego i politycznego kraju. Dzisiaj społeczeństwo szwedzkie stoi przed równie wielkimi wyzwaniami społeczno-ekonomicz- 
nymi. Szwecja należy do krajów, w których urbanizacja i - co za tym idzie - zmiany w strukturze społecznej posuwają się szybkim krokiem naprzód. Idea powszechnej edukacji społeczeństwa i przygotowania go do funkcjonowania w nowych społeczno-ekonomicznych warunkach życia stanowi jakby gwarancję modernizacji i rozwoju Szwecji w pozytywnym kierunku. Uniwersytety ludowe powinny zatem nieustannie prowadzić żywą i adekwatną do rangi wyzwań dyskusję na ten temat i nieustannie podejmować nowe zadania edukacyjne odpowiadające pojawiającym się nowym potrzebom społecznym ${ }^{3}$.

\section{Bibliografia}

Bron-Wojciechowska A. (1977), Wspótczesne uniwersytety ludowe w Skandynawii, [w:] A. Bron-Wojciechowska (red.), Uniwersytety ludowe w Polsce i za granica, LSW, Warszawa, s. 150-170.

Byczkowska S., Maliszewski T. (2005), Scandinavian Inspirations: Looking for a True "School for Life", [in:] T. Maliszewski, W. J. Wojtowicz, J. Żerko (eds.), Anthology of Social and Behavioural Sciences. 20 Years of Co-operation between Universities in Linköping and Gdańsk, LiU, Linköping, s. 135-147.

Byczkowski M., Maliszewski T., Przybylska E. (eds.) (2003), Folk High School School for Life, Kaszhubian FHS, Wieżyca.

Hall B. (1996), Co sobq reprezentuje szwedzki uniwersytet ludowy?, [w:] H. Hovenberg et al. (red.), Materiaty Projektu „S(z)koldem”: Demokratyzacja oświaty. Z doświadczeń polskich i szwedzkich/“S(z)koldem” Project Papers: Democratization of Education, Expereriences from Poland and Sweden, LiU, Linköping-Gdańsk-Poznań, s. 138-142.

Hovenberg H. (1976), Wznowienie wspótpracy między polskimi i szwedzkimi uniwersytetami ludowymi, „Oświata Dorosłych”, nr 4, s. 238-239.

Hovenberg H. (2003), Szwedzkie uniwersytety ludowe: kształcenie i dokształcanie nauczycieli, [w:] M. Byczkowski, T. Maliszewski, E. Przybylska (red.), Uniwersytet ludowy - szkoła dla życia, KUL, Wieżyca, s. 413-421.

3 W listopadzie 2012 roku opublikowany został w Szwecji nowy, krajowy dokument o treści oświatowo-politycznej (zob. SOU 2012, s. 72), który z pewnością będzie służył do podejmowania decyzji politycznych dotyczących roli i zadań szwedzkich uniwersytetów ludowych w przyszłości oraz finansowania ich działalności. Dokument ten ma również za zadanie uwidocznienie i naświetlenie ogólnej roli oświaty dorosłych, uzupełnienie wytycznych dotyczących całokształtu jej zadań, przed którymi stają również uniwersytety ludowe oraz wytyczenie kierunku ich rozwoju. Inicjatywa stworzenia tego dokumentu powstała w szerokich środowiskach oświaty dorosłych i kręgach edukacyjnych zajmujących się ideą uniwersytetów ludowych. 
Hovenberg H., Maliszewski T. (1996), Szwedzka Akademia Demokracji jako forma wychowania dla demokracji, [w:] J. Żebrowski (red.), Edukacja w społeczeństwie obywatelskim i system wartości, GTN, Gdańsk, s. 77-89.

Ismailov E., Maliszewski T. (2003), Szwedzkie szkolnictwo średnie dla dorostych u progu XXI wieku. Wybrane problemy, „Rocznik Andragogiczny”, s. 99-112.

Kasimir I. (1987), Kształcenie nauczycieli oświaty dorosłych w Szwecji, „Oświata Dorosłych", nr 5, s. 302-307.

Maliszewski T. (1997), The Poles and the Swedish folk high school. A historical outline of mutual contacts, [w:] E. Olszewski (ed.), Poles in Scandinavia, Panta, Lublin, s. 361-383.

Maliszewski T. (2003a), Rozwój idei uniwersytetów ludowych w Danii, Niemczech, Polsce i Szwecji. Podsumowanie, [w:] M. Byczkowski, T. Maliszewski, E. Przybylska (red.), Uniwersytet ludowy - szkoła dla życia, KUL, Wieżyca, s. 138-143.

Maliszewski T. (2003b), Wokót uregulowań prawnych funkcjonowania szwedzkich uniwersytetów ludowych (folkhögskolor), [w:] M. Byczkowski, T. Maliszewski, E. Przybylska (red.), Uniwersytet ludowy - szkoła dla życia, KUL, Wieżyca, s. 297-303.

Maliszewski T. (2003c), Z dziejów uniwersytetów ludowych na terenie Szwecji, [w:] M. Byczkowski, T. Maliszewski, E. Przybylska (red.), Uniwersytet ludowy - szkoła dla życia, KUL, Wieżyca, s. 125-137.

Maliszewski T. (2007), Szwedzkie uniwersytety ludowe - spojrzenie z drugiej strony Bałtyku, „Edukacja Dorosłych”, nr 1-4, s. 49-68.

Maliszewski T. (2008a), Den svenska folkhögskolan - En betraktelse från andra sidan Östersjön, ("Vuxentubildarcentrums skriftserie 19"), Linköping: Linköpings universitet.

Maliszewski T. (2008b), Szwedzko-polskie kontakty oświatowe w latach 1945-1989: casus edukacji dorosłych, „Rocznik Andragogiczny”, s. 168-188.

Maliszewski T. (2014a), Skandynawski eksperyment andragogiczny w Skattungbyn $k$. Orsa, „Studia Dydaktyczne”, t. 26, s. 305-316.

Maliszewski T. (2014b), Swedish Folk High Schools (Folkhögskolor): Past and Present. A Look from the Polish Perspective, "Universal Journal of Educational Research", Vol. 2, no. 4, pp. 387-395 [DOI: 10.13189/ujer.2014.020407].

Nowak J. (1985), O szwedzkich uniwersytetach ludowych, „Oświata Dorosłych”, nr 1, s. $37-41$.

Olsson K. (2003), Kurs Resursbevarande försöjning jako przykład Szkoty dla Życia, [w:] M. Byczkowski, T. Maliszewski, E. Przybylska (red.), Uniwersytet ludowy - szkoła dla życia, KUL, Wieżyca, s. 335-339.

Petterson A. (1947), Młodzież i uniwersytety ludowe w Szwecji, „Siewba”, nr 3-4, s. 66-73.

Półturzycki J. (2009), Edukacja w Szwecji, IteE, Radom, s. 159-198.

Półturzycki J. (2010), Edukacja dorostych w Szwecji, [w:] A. Frąckowiak, J. Półturzycki (red.), Edukacja dorostych w wybranych krajach Europy, t. 1, WA Żak, Warszawa, s. 185-221. 
Reichberg P. (2003), Szwedzkie uniwersytety ludowe, [w:] M. Byczkowski, T. Maliszewski, E. Przybylska (red.), Uniwersytet ludowy - szkoła dla życia, KUL, Wieżyca, s. 118-124.

Sjöström J., Hedscher J. (2012), Behovet av folkhögskolor är störst i förorterna, „Dagens Nyheter", z 7 stycznia 2012 r.

SOU (2012), Folkbildningens samhällsvärden - En ny modell för statlig utvärdering. Betänkande av Folkbildningsutredningen, SOU 2012:72, Stockholm: Statens offentliga utredningar.

S. W. (1966), Wymiana doświadczeń między polskimi i szwedzkimi uniwersytetami ludowymi, „Oświata Dorosłych”, nr 3, s. 134.

Thell U. (2014), Polskt-svenskt samarbete på Albins, „Helsingborgs Dagblad” z 2 czerwca 2014 r.

Tingdal B. (2012), Albins satsar på surfplattor, „Folkhögskolan”, nr 3, s. 20-24.

Turos L. (1967), Uniwersytety ludowe w Szwecji, „Oświata Dorosłych”, nr 4, s. 213-216 .

Turos L. (1974), Oświata dorosłych w krajach skandynawskich. Wybrane problemy w ujęciu historycznym, Ossolineum, Wrocław.

Wojtowicz W. (1966), Jak uniwersytety ludowe w Szwecji przygotowuja do samoksztatcenia, „Oświata Dorosłych”, nr 8, s. 433-435.

Wojtowicz W. J. (1985), Uniwersytety ludowe w Szwecji. Ideały i rzeczywistość / / Folkhögskolor i Sverige. Ideal och verklighet, Linköping: Fortbild i Linköpings högskoleregion.

Wojtowicz W. J. (1991), Z działalności uniwersytetów ludowych w Szwecji, „Zeszyty Naukowe Uniwersytetu Gdańskiego. Pedagogika - Historia Wychowania”, nr 19, s. 163-170.

\section{Netografia}

Folkhögskolornas informationstjänst (2012a), Allt fler ska kunna läsa in gymnasiet på folkhögskolan, http://www.folkhoskola.nu/Nyheter/Meddelanden-fran-FIN/2012/Folkbildningsradet (dostęp: 27.03.2012).

Folkhögskolornas informationstjänst (2012b), Om folkhögskolan, www.folkhogskola.nu/Om-folkhogskolan/Studiestodsformer/ (dostęp: 25.03.2012).

Albins folkhögskola (2014), Kursinformation, www.albins.nu (dostęp: 02.04.2014). 
